\title{
Abstract
}

\section{Historic settlements and pastoralism in the Arctic and Tibetan Plateau: 3 towards a comparison}

4 Historic settlement processes of respectively the Northern Sámi and Western Tibetan 5 pastoralists, have so far not been subjected to any comparative social science analyses. This 6 study contributes to such a conceptual platform, drawing on the constructs dwelling, 7 settlement, herding unit, pastoral landscape and the labor-animal-pasture triangle.

8 Ethnographic and archival evidence of transitions from sedentary/semi-sedentary to full-

9 fledged pastoralist societies and transitions from a pastoral adaptation to sedentary and semi10 sedentary life are analyzed and debated in light of the influential theoretical proposition of a categorical difference between a nomad's and a farmer's dwelling. At the core of this comparative inquiry is two highly dynamic pastoral herding societies. It is argued that a comparative approach to the study of settlements requires a theoretical and analytical reframing - informed by a more adequate comprehension of the dwelling-settlement nexus. This preliminary scrutiny of dwelling designs and settlement practices of Sámi and Tibetan pastoralists indicates that nomads in both regions internalized and activated different spatial models and inventively mediated between different spatial models according to seasonal or irreversible shifts of leaving the nomadic adaptation altogether. Further rigorous empirically inquiry into accommodation, innovation, and possible failures to mediate gaps in the making/remaking of dwellings and settlements are called for.

\section{Keywords}




\section{Historic settlements and pastoralism in the Arctic and Tibetan Plateau: Towards a comparison}

Tone Bleie

Contact: Professor Tone Bleie: tone.bleie@uit.no. Department of Social Sciences, UiT - The Arctic University of Norway.

\section{Introduction}

This paper aims to examine recent research on historic settlements of respectively the

Northern Sámi and Tibetan pastoralists. Social scientists devoting themselves to the study of settlements in the High North and the Tibetan Plateau have hitherto not been much preoccupied with the relevance of each other's work to their own. Here I make an effort to advance a comparative approach to future studies of settlements in a pastoralist context. ${ }^{1}$ In order to in order to tease out comparative intakes and useful arguments, I examine current research on how historic changes of Northern Sámi pastoralism affected settlements with my own recent work with Tibetan colleagues of historical pastoralist settlements in the Western Tibetan Plateau. $^{2}$

The current interest in contributing to a comparative turn emerges from a longstanding research partnership involving Norwegian natural and social scientists and native scholars from The Tibetan Autonomous Region (TAR) in China (Fox et al., 2004; Fox and Tsering 2005; Yangzong 2006; Dorji et. al., 2010; Næss 2013; Tsering and Bleie 2016, 2017; Bleie and Tsering 2017). Collaborative research between the University of Troms $\varnothing$ on the nomads of the Tibetan Plateau is an evolving sub-field over the last 15-years. Realization of the merits of comparative studies in the social sciences and humanities is notably slower than in the natural sciences. This paper represents a modest attempt to stimulate comparative nomadic studies and facilitate cooperation between scholars of the High North, of the Tibetan Plateau, and of neighboring pastoralist areas of Central Asia. In a review of Khazanov's magisterial 
comparative study Nomads and the Outside World (1984), Ingold (1985) rightly bemoaned the fact that most comparisons have been intraregional in scope. His regrets three decades later largely rings true as it comes to interregional studies of Northern reindeer herders and yak herders of the Tibetan Plateau.

By way of introduction, I would like to explain the paper's comparative and theoretical underpinnings. This author received her training at an anthropological department where Fredrik Barth and several other professors insisted that we students should understand pastoral studies as a comparative endeavor (Barth 1959, 1961, 1966, 1969). Comparison was not confined to intraregional studies of the pastoralists of Africa's semi-dry savanna belt. The pastoralists of the Sahel belt could profitably be compared with highland pastoralists eking out a living with their herds in Himalaya's rain shadow. The theoretical locus was social forms, generated by behavioral patterns, be they herder-herd-pasture dynamics, relations between nomads and the sedentary society, and dwellings. This stance came to influence later processual and actor-based anthropological models of pastoralist movements (see, e.g Dwyer and Istomin 2008), and, indeed, this author's enduring theoretical outlook.

The interregional comparison of pastoralists making a living with their mobile herds under somewhat similar environmental conditions historically and contemporaneously, builds in brief on the following assumptions. Historically, pastoralist herders and their flocks in the circumpolar North and the Tibetan Plateau managed to adapt to the extremely adverse conditions in some of the world's harshest mountain environments. Both regions undergo extreme temperature variation between long, windy, and bitterly cold winters, transitory seasons (when seasonal migrations could take place), and brief, moderately warm summers. Several environmental and ecological parameters are rather similar in the two regions, including seasonal climatic variations, extensive use of Alpine mountain meadows as pastures and hunting grounds, and an abundant wildlife providing an excellent source of protein, furs, 
and hides for consumption and exchange. Both mountain regions offer niches for pastoralism - a highly specialized adaptation of human herders and semi-domesticated flock animals. In both regions, nomads rely on mobility to manage resource variability. The same mobility imposes certain preconditions for their dwelling modes. Both yak and reindeer can survive outdoors in freezing temperatures. These similarities aside, reindeer herders in circumpolar areas, including Northern Norway, unlike yak herders, combined inland herding and foraging with fjord side herding and exploitation of marine resources. The differences in transhumance cycles between inland and fjord, on the one hand, and mountain dwellers, on the other, do not pose serious difficulties to our comparative interest.

The paper is devoted to a discussion and re-analysis of the history and ethnography of dwellings and settlements, set within a comparative history of the transition to pastoralism. Empirical evidence is drawn from studies on Sámi reindeer pastoralists in Northern Norway in the eighteenth and nineteenth centuries, and from the Tibetan Plateau in the seventeenth and eighteenth centuries. The first half of the paper will explain my theoretical approach to the dwelling-settlement nexus, which I apply first to recent historical evidence of reindeer pastoralism. The second half will analyze the black yak tent as a dwelling mode in a relation to the construct of settlement, drawing on my own collaborative research in the Western Tibetan Plateau, as a basis for arguing the comparative case.

It is beyond the scope of this paper to undertake a comparative discussion within a first-third pole framework of the strikingly similar transformations in TAR/China and Northern Norway from the 1960s onward of nomadic adaptations to strictly state-regulated herding regimes. These transformations are characterized by permanent settlements and resettlements and altered herd management regimes, both a response to climate changes while also affecting fragile environments. My colleagues from China and I would definitively want to prioritize a first-third pole perspective in a possible next phase in our collaborative 
research. We have noticed that in both countries, government-sponsored policies including housing schemes, subsidized fencing, and a range of other incentives and disincentives have had rather dire consequences. They should warrant comparative research on how pastoralists in both regions negotiate new compromises between sedentary and mobile lifestyles, the new, presence of extractive industries, mass tourism and climate-induced environmental change. These public policies and programs have so far stimulated intra-regional or case-oriented studies. Of importance here are works that avoid simply appropriating ideologically laden notions of permanent settlements/resettlements and offer an informed critique of state-centric or civil-society centric constructs of settlements and dwellings (see, e.g. Nilsen and Mosli 1994, Wheelersburg and Gutsol 2010, Huber and Blackburn 2012, Bjørklund 2013a, Næss 2013; Gaerrang 2015, Ptackova 2015).

\section{Approaching the study of the settlement-dwelling complex}

Permanent settlements in both regions were until as late as the 1960s confined to the rims of vast nomadic realms that had existed for several centuries, even millennia. In Northern Norway - as elsewhere in the High North and in the Tibetan Plateau - mobile tents constituted the principal dwelling form. Apart from the prominence of research on permanent settlements as a central societal force behind fundamental changes in pastoralist societies, the term settlement nevertheless figures in historically oriented literatures that seek to comprehend the drivers behind the rise, expansion, decline, and structure of migratory herding societies. This body of literature seeks to understand certain fundamentals of herding regimes in terms of their dynamic interfaces with agricultural civilizations and state formations, sophisticated skill base, changes in social organization and transhumance cycles, conservation practices and the dwelling-settlement nexus. In recent years, the explanatory, 
cross-cultural relevance of the settlement-dwelling nexus has attracted theoretical reflection and a more rigorous methodological scrutiny. Inspired and informed by these developments, this paper employs a diverse toolbox equipped to interpret both ethnographic and archival evidence of what appear to be different operative spatial models underlying the diversity of the dwelling-settlement nexus in both Northern Norway and Western Tibet.

Arguably, the constructs of $d w e l l i n g$, herding unit, and landscape may prove especially useful as comparative intakes to the study of settlements since they build on certain assumptions. The first of these may appear trivial: Nomads generally eke out a living in arid environments. Tent-like, nomadic, iconic dwellings, be they in the Arctic, Central Asia, the Sahel, or Middle East, shelter humans and their domesticated animals against freezing winds, sweltering heat, sandstorms, insect swarms, and intruders, be they wild animals, robbers, or raiders. The Northern Sámi laavu, the Tibetan black yak-hair tent or dra nag, or the Tuareg red goatskin tent or ahakit, to name a few, all provide lifesaving shelter. Their interiors in addition to pole-supported leather or woven wool clad membranes, are intricately designed and utilized social spaces. The interiors would have delineated places for hearth, worship, cooking, and dining, sleeping space, storage, processing, and production. More conceptually intriguing, dwellings of pastoralists constitute microcosms of their cosmologies, exhibiting striking similarities and certain unique traits within and between pastoral belts. A related argument is that these iconic dwellings as material structures are somehow integral to nomadic settlements as an analytical category. Intuitively, we may assume that individual mobile dwellings are building blocks of these realms, which extend in time and social space. The gaze of a Western observer may instinctively take for granted that any vast nomadic realm is constituted by tent-like dwellings fanning out as dots or clusters across enormous pasturelands or landscapes. ${ }^{3}$ 
Trained in anthropology, one learns how to be self-reflective about any landscape as a construct of tacit propositions about its social and natural features. Certainly, this author's lenses were also formed by looking at Western or Eastern sedentary peasant civilizations and science, notably cartography's and architecture's definitions of what constitutes a house (hus) and a settlement (bebyggelse or bosetting). The term settlement is not only understandable (for the reasons stated above) by a team of Tibetan and Norwegian researchers, it carries distinct political and normative connotations, which simply cannot be disregarded by this author as a participant in a Sino-Norwegian collaborative research endeavor. This author's reconceptualized notions of landscape, dwelling, settlement and the space-place dichotomy, is influenced by internal critique and theory formulations within respectively social and cognitive anthropology. The first investigates cultural landscapes as molded through local practice and as a cultural process (see, e.g. Hirsch and O'Hanlon 1995; Ingold 2000; Low and Lawrence-Zuniga 2003). The second is informed by the way the neuropsychology of spatial orientation conceptualizes an egocentric model of landscape orientation and a socio-centric model based on, for example, celestial coordinates and watershed contours (Shore 1996, 276280). My principal reasons for proceeding as cautiously as this, is because I want to make relevant recent decades' rigorous theory development in social and cognitive anthropology, ethno-archeology, and cultural geography, which enriches the comparative study of dwelling, landscape, and settlement.

Recent contributions to the study of dwelling should stimulate scholars to pay more rigorous attention to testing theoretical arguments, both abstract reasoning and concrete propositions, which may be tested against ethnographic evidence. Such insights can be brought to bear on this paper's preoccupation with settlements. We obviously should strive to gain insights beyond interrogating how material features, including building materials and skill sets, constitute vernacular architecture. We may have to shift our focus to grappling with the nature 
of (dis-)continuity between the built and the surrounding landscape. In the high mountains of Western Tibet, the degree to which the exteriors of traditional tents merged with the surroundings would vary with the seasons. The analytical issue of dwellings' exteriors and submergence within the surroundings aside, more interesting questions about dis/continuity between the built and expansive mountain realms depend on conceptualizing the spatial organization of the interiors. Pastoralists' notions of dwelling and encampment realm are intertwined with their cosmological ideas, enacted in their highly skilled practices in ways we need to better comprehend. At the core of this inquiry is the pastoral mobile herding regime.

Said more explicitly, a well-informed approach to the study of settlements requires a theoretical and analytical reframing - informed by a more adequate comprehension of the defining traits of the herding regime - which pivots around the herder-herd-land triad.

The work of anthropologist Tim Ingold represents a theoretical view of the conical mobile tent or lodge as fundamentally different from any permanent dwelling. The tent with its wooden frame, converged at the apex, forming an interior space with the hearth at its center is a sky-earth structure, an enveloped form mediating earth and sky (Ingold 2000, 63-5; 2011, 211; 2013, 13-28). Ingold takes issue with view in his and my discipline (and shared in cultural studies) of the tent or lodge as vernacular architecture, a structure based on a "local" design, crafted into a background landscape, whether this is explicitly articulated or not. His processual "organic" earth-sky theory, Ingold maintains, is a far more adequate representation of key facets of indigenous cosmology and skilled practice. The nomadic dwelling is a matrix of earth, the sacred hearth and the textile or fur membrane. It shields old and young against winds and wild animals and defines a sheltered space for life-sustaining reproductive, productive, and other sense-making processes. In Ingold's scheme, the nomad and the farmer live under same sky, touch similar elements and inhale the same air. Here the similarities end. Their engagement with the earth they inhabit and the epistemologies of their respective 
inhabited or lived realms differ fundamentally, creating different constellations of what one may call mindscapes and landscapes. These distinct epistemologies structure at a more concrete observational level different notions of human-land and human-animal relations and land custodianship.

Ingold's bold postmodern theorizing, firmly anchored in an extensive philosophy of science examination of paradigmatic sciences (architecture, art history, engineering, and geography) offers much food for thought. His arguments should be understood as an ideal model that is good "to think with," yet not necessarily verifiable empirically in all empirical instances. As I shall argue, pastoralists may internalize and activate different spatial models and inventively shift and mediate between spatial models in their own seasonal dwelling and settlement practices. Our own research on spatial models of Tibetan nomads in the seventeenth century, reveal how conversant they were with monastery complexes, which were architecturally designed monumental buildings. The question is how different the spatial models underlying a monastery are from a nomadic tent. In view of the finding that quite a number of early nomads of the Chang Tang Plateau came from farming communities in Eastern Tibet, we are also trying to explain the adaptation and survival skills of farmers turned pastoralists. Works on the Northern Sámi during the heydays of pastoralism, show how they shifted back and forth between highly mobile and semi-permanent dwellings and settlements. There was a trickle of nomads that left the specialized pastoralist adaptation and resettled in permanent Sea Sámi settlements, carving out a living combining fishing and agriculture with husbandry and hunting. Ingold's theoretical propositions about a categorical fundamental difference between nomads and farmers dwellings may nevertheless be useful to keep in mind, as we attempt to analyze transitions from sedentary and semi-sedentary to a full-fledged mobile society (also exiting to sedentary adaptations) which would seasonally 
embrace semi-sedentary life in close proximity to sedentary settlements, be they farming villages or monasteries.

\section{The debate on origins of Sámi pastoralism and settlements}

My interest in this evolving field of research on the origins and defining features of Sámi reindeer pastoralism is rather eclectic, and mostly confined to empirical evidence (direct and indirect) of settlement structures, dwellings, and contributions to theories on the settlementdwelling complex.

Offering a persuasive, evidence-based critique of the theory of large-scale, unilineal transformations as a shift from hunting and gathering to reindeer herding, Ivar Bjørklund (2013 a,b) argues that the Sámi pursued various livelihood strategies down the ages involving different combinations of hunting, fishing, and reindeer husbandry. Unpacking a fascinating analysis that combines ethnographic insights with text-based evidence, Bjørklund argues that full-fledged pastoralism only evolved in the eighteenth century (2013a, 186). He demonstrates the importance of evidence of how herders' household organization, was structured around productive and reproductive tasks that affected dwellings' design and functionality. This series of arguments can be taken further, offering crucial insights into settlement patterns.

Addressing a joint work of historian Lars Ivar Hansen and archeologist Bjørnar Olsen (2004), Bjørklund argues that crucial changes in settlement patterns were a direct effect of a long-term transition, rather than a shift from hunting to pastoralism. This specialized adaptation emerged from a long historic period (dating back to prehistoric times) during which different combinations of hunting, gathering, fishing, and domestication (of dogs and reindeer) coexisted. With the rise of pastoralism, the mobile bealljigoahti became a principal dwelling. It consisted of two pairs of double-arched poles (beallji) and a dozen of straight poles. The construction had a proper doorway and was covered with woven fabric. The lighter 
conical lavvu, akin to the principal dwelling type of circumpolar peoples of the U.S., Canada, and Russia, was used during seasonal migrations. Both designs were ingenious adaptations and functioned to accommodate dwelling requirements during migrations and stationary seasons under new extensive herding regimes. What is enlightening for my interest in the settlement-dwelling complex, is Bjørklund's argument about shifts in livelihoods based on a rigorous household analysis. Making use of a range of visual and textual historical sources, including medieval drawings, travelogues, and other written sources, he succeeds in establishing evidence of how a household-centered and kinship-based social organization responded to and exploited a range of opportunities to harvest nature's bounty and to deploy human talent in taming the reindeer, a wild flock animal.

A brief commentary is tempting on discernible parallels between Bjørklund's preoccupation with a household mode, Ingold's practice-based approach to cosmological, political, and practical meanings of mobile dwellings and works of Henrietta Moore (1986) and Vigdis Broch-Due $(1991,1993)$ on pastoralists in the East African savannas. The latter two scholars primacy of gender theory aside, all actually apply practice-oriented theory to household models and the construction of social space, body, place making and (en)skilling processes, unraveling how dwellings, homesteads, and nomadic settlements are made and unmade. What is important for this paper's analytical discussion is how these related strands of scholarship all contribute to a fine-grained interrogation of how both humans and herd animals (consciously and instinctively) form, accommodate, mediate, or transform shifts (from incremental to radical) through their mutually constitutive and quite intimate bonds. These shifts have profound implications for the structure of the functionality of dwellings, homesteads, and encampment realms.

In the remainder of this section, I shall continue to engage not only with Bjørklund's insights, but also Hansen's intricate approach based on economic history to understand how 
the political economy of pastoralists and their settlements was formed at the pastoralist-state interface. I will also make selective use of Nils Mikkel Sara's works on Siidas as kin-based herding units - before turning in the next section to my own research on the dwellingsettlement nexus in Western Tibet's formative nomadic society.

Building his evidence base against the postulate of a transformative shift from a hunting to pastoralist existence, Bjørklund argues for a more balanced weighting of internal and external drivers. Such a two-sided approach, he maintains, weakens the singular trajectory theory from hunting to pastoralism argument. Evidence of somewhat different household adaptations in the areas of Porsanger-Karasjok and Varanger are presented, showing that variations largely reflected local fluctuations in resources and environment. Different combinations of hunting, fishing, husbandry of semi-tame reindeer and sheep, processing of milk, and hide and fur preparation, allowed for a reordered a gendered household organization. Women and men partook in a variety of trade and barter arrangements of various geographical scale. The trade and barter argument not only lends evidence from data collected by economic historians, but also from an elaborate drawing on the front cover of a book by a priest named Schefferus, originally published in 1673, a collection of reports from missionary journeys in Northern Sweden. The front cover depicts a man and woman with a tame reindeer on the move. Analyzing the picture, Bjørklund takes particular notice of their leather clothing and the kinds of utensils and implements they carry. Arguably, from a gender point of view, it can be interpreted as testimony to the critically interrelated nature of reproduction, consumption, and production. The woman leads a bouzu that carries her (possibly the couple's own) infant in a komse. The drawing graphically portrays salient facets of a mobile household prior to specialized pastoralism. It is safe to assume the picture would not have been chosen as the cover, had the scene been exceptional. Schefferus, a prominent cleric and traveler, wanted to show his readers a familiar (rather than 
a rare) observed episode. Couples undertook bartering journeys with dependents, even small children. Sámi women were herders, hunters, gatherers, and processors of many animal, fish, dairy subsistence and barter products. Breastfeeding women would travel to exchange and barter, bringing along infants and toddlers. Draft reindeer relieved parents from having to carry dependents and goods over the tundra. The boazu toddled along with their precious human cargo. The heat given off by the large animal could be a lifesaver for a child in a komse when temperatures dropped far below zero.

An older drawing of a hunting scene offers additional evidence for Bjørklund's (2013a, 177) analysis of quasi-human relations, especially with dogs. The drawing depicts a group comprising a female and male hunter and their faithful dog chasing wild game. In this author's understanding, more evidence could be elicited from the picture. The drawing is an extraordinary graphic expression of a mobile integrated encampment realm. The female hunter's hair is shown blowing in the wind. The group is about to cross a vast mountain area on skis. The late-sixteenth-century artist placed them above a mountain range in order to communicate the group's formidable range. Two tent-like dwellings are engraved floating above the undulating land, suggestive of their mobile character. The artist may well have intentionally omitted to mark any domestic realm set apart from the public mountain realm for the simple reason that the private/public distinction did not exist.

\section{Evidence of a full-fledged pastoralist adaptation}

According to Bjørklund (2013b, 72), from the eighteenth century onward a significant change in dwellings took place as a result of Sámi adaptation to pastoralism. Both different tents and permanent turf huts became essential seasonal dwellings. They were built of local materials and from durable woolen textiles bought from the Sea Sámi. The inland Sámi's quest for a combined livelihood strategy coalesced with their herds' instinctive inclination to 
migrate into an intricate, annual transhumance cycle for herders and animals. They would spend the often bitterly cold winters in the vast inland plateau, currently divided by the border between Norway, Sweden and Finland. Before the sun melted the snow-clad tundra, humans and animals would set out on an arduous long journey across the plateau and along watersheds to the rich fjord areas of what are currently the Norwegian counties of Finnmark, Troms and Nordland. They were skilled in the use of the wild goddi deer, which instinctually undertook the annual migration from inland to coasts. In the wake of the goddi semi-tame boazu followed, in search of nutritious spring and summer pastures. In the fjord areas, the nomads lived in turf huts, akin to the Sea Sámi dwellings, from June to August/September.

Evidence of a full-fledged adaptation to a pastoralist way of living can be gleaned from herd size, fluctuating seasonally due to slaughter, mortality, and fecundity. More than a cora (of 30-40 animals) was required for consumption, clothing, and trade for a couple with offspring (Bjørklund, 2013a,182). Indeed, a specialized pastoralist regime required a winter herd of around 200-250 animals (Bjørklund 2013a, 183). The resulting siida organization developed new notions of customary justice, social values, and altered household strategies and settlements as a response to quite significant changes in human-reindeer relations. The semi-tame reindeer (boazu) perceived as wealth, became individualized property. Ownership was literally inscribed into the reindeers' bodies by marking one ear of each animal. Larger herds resulted from a number of drivers/factors. External causes were directly or indirectly related to the expansion of the Danish-Norwegian, Swedish, and Russian states. Some of the main factors behind the increase in herd size were the expansion of regional markets - which spurred local trade - population growth, and diminishing supply of wild goddi due to overexploitation. One crucial factor not be overlooked, the development of a particular skill: the (semi)domestication of large flocks of reindeers. Increasing labor shortages limited people's ability to learn and perform demanding everyday tasks, altering household strategies 
and settlement organization. It became not only opportune, but necessary to mobilize the larger ego-based kin group in order for woman and men to juggle new demanding herding requirements and other productive and reproductive tasks. The Sámi’s bilateral kinship system proved functional for enhanced daily, seasonal cooperation, and labor supply.

A number of scholars have sought to theorize the dynamic intertwined cultural, social, and economic facets of the bilateral kin-based siida organization. Without detailing similarities and differences between the "new" and the "old" siida, one may assume that an ego-based kin group gradually evolved into a functional, band-like herding organization that optimized the people-land-pasture triad (Bjørklund (2013b, 185). The new bands were highly flexible and responsive to pasture access, herd size, herd composition, and tax borders (Vorren 1978, Bjørklund 2013). In a major recent study of the siidas conceptualized as a combined social-ecological system, Nils Mikkel Sara (2015) offers an analytical toolbox and empirical evidence enriched by his own practice as a reindeer herder in Finnmark.

Sara's theoretical point of departure $(2015,53-60)$ is partly based on earlier collaboration with Ole Henrik Magga's (2001) and Nils Oskal's (1995, 2001), and on the debated works of Bjørklund, in addition to the Canadian anthropologist's Fikret Berkes' influential studies (2008, 2009). In Sara's scheme, indigenous ecological knowledge practices must ground any social scientific understanding of reindeer herding and the herding groups' mobile settlements and dwellings. Sara uncovers an intricately rich ethnography of the siida's significance as tacit knowledge. Such knowledge is held not only by humans, it is constituted within an intimate human-animal bond, in which reindeer "opinion" counts and the "landscape" is ever present spiritually, in a qualitatively different manner than in the European-oriented sense discussed earlier (Sara 2015, 167-175). Such intriguing contemporary insights into the multi-vocal siida concept may help to clarify Bjørklund's hypnotized shift to a new incongruence between dwelling, herding group, and settlement. 
As discussed, Bjørklund, Hansen and others maintain that taxation was one of the important drivers behind the transition from combined hunting and herding to wholesale reindeer pastoralism. Herding units composed of single households were taxed in their own demarcated territories well into the eighteenth century (Vorren 1978). As larger networks fanned out across the expansive tundra, these growing siida clusters defined the extent of their respective nomadic realms. Outreach in terms of geographical scale and numbers of herders and herd varied throughout the migratory cycle. The annual cyclical drift between inner mountains and fjord-side summer pastures became institutionalized during the eighteenth century. The nomads' seaside turf huts (bealljigoahti or gamme) were similar if not an identical to the functional interior organization of the turf huts of the Sea Sámi, who manufactured hut covering blankets of sheep's wool (rátnu) during the winter months (Bjørklund 2013b, 72). How to best conceptualize the winter camps and the fjord side as settlements? In their winter pastures, the Sámi had been the sole inhabitants for millennia, itinerant traders and tax agents aside. The fjord areas were no longer the sole realms of the Mountain and Sea Sámi. The rich fisheries and cultivatable land had attracted inner-fjord settlers, and thriving fishing communities (fiskevar) along the coast profiting from the rich Atlantic fisheries. However familiar the Sámi were with public buildings (like the Vardøhus Fort and medieval churches) and private houses (from modest timber huts to mansion-like trading houses or handelshus), they retained their ancient turf hut (gamme) with certain functional modifications (see e.g Falkenberg 1941; Niemi 1983; Petterson 2013). Only increasingly harsh assimilation policy in the nineteenth century led Sea Sámi to shift to ordinary farmhouses, but even so, they retained their turf huts for a range of practical and spiritual purposes.

In order to solidify our empirical grasp on the drivers and spatial outreach of settlements, the work of the economic historian Lars Ivar Hansen (see e.g. 2012, 2013) on 
relations and interaction between the coastal and inland Sámi and surrounding state formations (from the late Middle Ages) is extremely helpful. Reliable taxation lists constitute a prime source of evidence. The pastoral society was affluent, and provided room of maneuver for pastoral producers and traders. Individual men were levied tax (Hansen 2012, 222). So was households as consumptive units, designated in the records as hearths ( $r \phi k)$ or hunting units (bow). Since these dwelling and production units were elements of larger siida clusters, Hansen has used the records to draw up detailed spatial maps of the seasonal, annual, and long-term movements of households and siidas, whose members are in these records.

What is fascinating for our specific inquiry, is how Hansen's mapping of the spatial dynamics of Mountain Sámi's siida wanderings between mountain and fjord and of the Sea Sámi's, also unravels the scale of settlements. These siidas opted for a semi-sedentary adaptation along the Tana, Alta, and Varanger fjords of Finnmark. Studying this body of evidence, one notes the optimal location of the market places for the mobile lifestyle of the main Sámi camps on Finnmark's vast tundra and winding coastal rim, penetrated by fjords. The patterns of mobility and settlement show striking variations, indicative of relatively short seasonal movements between mountains and fjord pastures, but also intricate fjord-side patterns of movement. People settled in camps for a couple of years, before moving to new locations near the major salmon rivers and attractive fjord basins. The latter is testimony to a kind of unidirectional migratory process. Other herding units chose a cyclical mobility pattern and moved every third or fourth year, returning subsequently to their previous settlements. Those who chose to settle in the fjords pursued livelihood strategies that combined usufruct rights to pastures, fishing grounds, game territories and access to local and regional markets, subject to fluctuations in the Hanseatic and Danish-Norwegian trade of the 1560s-90s (Hansen 2012, 236). These dynamics drove the formation of Sea Sámi farms (gårder) and hamlets (bygder). 


\section{Toward a comparison: The rise of a pastoral society in Western Tibet}

431

432

433

434

In the circumpolar North, early humans arrived in the Upper Paleolithic around 36,000 years ago (Seguin-Orlando et al. 2014) and in the more accessible parts of the Tibetan Plateau not many thousand years later, since the climate was considerably warmer than now (Brantingham, Olsen and Schaller 2001). Husbandry emerged in certain parts of Central, Eastern and Western Tibet at least 4,000 years ago, driven by the advantageous triangular relationship between humans, semi-domesticated animals, and pastures and a dynamic exchange with early agricultural civilizations.

The modern history of yak and sheep nomadism in the southwestern Chang Tang in the Western High Plateau, is a fairly recent adaptation, not unlike Sámi pastoralism. I shall in this part of the paper presents a selection of findings from our current project on the incremental rise of pastoralism in this part of the Plateau, findings which arguably "may speak to" the much debated but crucial historical insights of scholars on reindeer pastoralism. Pastoralism in Chang Tang dates at least back to the latter half of the seventeenth century. The reason for the late arrival of an extensive pastoral regime in this corner of the Tibetan Plateau is its extreme altitude of 4,500 meters or more. Chang Tang has been called a high altitude Serengeti (Grosvenor 1986) or literally "the rooftop of the world." Situated at a distance from the Silk Road, it was nevertheless connected to a number of ancient urban and trade centers in Far Western, Central, and Eastern Tibet and neighboring extended Himalayan region. The lower-lying parts of the plateau, at 2,500 to 4,000 meters had for millennia accommodated dynamic connections between nomadic formations (some highly expansionist like the Mongol empire) and permanent settlements with centralized authority variably exercised by monasteries, aristocratic elites, and imperial powers. 
Seeking to explain the origin of yak nomadism in Chang Tang some 350 years back, my colleagues and I have analyzed historical data and oral histories of intraregional migration events and settlements from the 1670s A.D. onward (Tsering and Bleie 2016, Bleie and Tsering 2017a, b). The hitherto unknown east-west migration history we have started to shed light on, reveals a volatile period of contending empires and internal turmoil in Eastern, Central, and Western Tibet in the late seventeenth and eighteenth centuries. In the wake of bitter regional and local armed conflicts, people looked for spiritual renewal and opportunities to escape and settle somewhere else. These factors drove farmers and nomads from communities in Eastern Tibet (currently Kham and Amdo Provinces) in a combined pilgrimage and search for new territory. They had heard revered spiritual masters (lamas) and returning pilgrims tell tales about an immense wilderness with excellent pastures and teeming wildlife surrounding their sacred landscape. At its center towered Mount Kailash at 6,638 meter - the Buddhist world's axis mundi - and the sacred turquoise Lake Manasoarvar.

Different Buddhist orders all vying for greater influence, had established monasteries in the region.

Our applied explanatory model specified push and pull factors in the source communities and the high-mountain destination area and traced accumulated migratory effects over several generations (Bleie and Tsering 2017). Using this theoretical approach, we are now constructing for the first time elements of a historical narrative of how south-western Chang Tang was gradually transformed from a largely uninhabited wilderness to a habitable nomadic realm, with a dynamic frontier and an increasingly well-functioning, if predominantly nomadic society. Discussing certain key findings, I shall make reference to the crucial insights of Bjørklund, Hansen and other colleagues on contextual drivers of reindeer pastoralism, including transformed herding units and settlement-dwelling complex, understood as formed within the dynamic relations of the herd-herder-pasture triad. 
As mentioned above, regional and national political unrest and local conflicts between warring clans in Eastern Tibet constituted the major push factors. Key pulling factors were the enormous pastures, abundant wildlife resources, and captivating Buddhist religious/mythic ideas of a promised land of bliss, religious merit, and abundant pastures (Ches ngags 2010, 53). These pioneers were members of the numerous Drongpa clan originating from a few identifiable source communities in Eastern Tibet. These Drongpa communities were renowned for their warrior tradition (Bleie and Tsering 2017). Groups of Drongpa households and their livestock set out on a several week-long and arduous migration across the plateau. In terms of occupation, rank, and repute these early migrants were a mixed lot. Some were defecting or fleeing warriors. Others were prominent religious figures or laypersons with a desperate wish to escape political enemies or grinding poverty and oppression on monastic estates. Quite a sizeable number were peasants, others came from nomadic families. The highly varied backgrounds are somewhat unexpected and consequential since a nomadic adaptation was the only viable option, save seeking admission into one of the ancient monastic orders located in the vicinity of the sacred Mountain Kailash (Blondeau and Steinkellner 1996; Huber and Rinzin 1995; Dowman 1997). The peasant migrants knew husbandry, but did not possess the necessary practical survival skills in high-elevations and had to team up in bands with newcomers from nomadic territories who knew how to construct and arrange a black yak-hair tent and herd mighty yaks, goats and sheep under extremely rough climatic conditions.

Legally speaking, Tibetan peasants and pastoralists could only obtain user rights to land on their lords' estates. However, the mighty landowning aristocracy and lords of monasteries in the ancient power centers in central and eastern Tibet had few or no means of directly enforcing land policies in a far-flung south-western corner of Tibet, including Chang Tang. The early generations of migrants fled land scarcity, exploitation, and internal strife 
503

504

505

506

507

508

509

510

511

512

513

514

515

516

517

518

519

520

521

522

523

524

525

526

were motivated by the prospect of allegedly unlimited mountain pastures. Those who arrived safely, lay claim to pastures north of the holy Mount Kailash. In the critical early years of forming mobile settlements and viable flocks of yak and sheep, they relied on each other for survival, guidance, and assistance. In this phase, the plateau's abundant wildlife was a stable source of protein and fur. Herders could also extract salt, a much sought-after barter item in the Trans-Himalayan trade network. The herding units were flexible bands composed of nuclear and extended Drongpa households who coordinated their daily affairs and work together to manage ever-increasing flocks and other vital productive and reproductive tasks. The dynamics of growing nomadic bands of kinsfolk interrelated by blood and marriage (necessary for management of larger flocks etc.) resembles the debated crucial importance of siidas in the development of reindeer pastoralism in the eighteenth century and the debate of the relative weight of external and internal drivers for its rise.

\section{Understanding the Drongpas' dwelling-settlement complex}

The eastern Drongpa migrants of nomadic background brought the ingenious black tent tradition to western Tibet. The fabric of the black tent was made of woven yak hair, patiently sheared over years and collected into large bundles. Nomads carefully plucked and combed their animals with a great amount of affection. They were acts of mutuality between humans and these majestic animals. The black tent as a process and design constituted a concrete manifestation of a symbiotic spiritual bond between humans and yaks. When hair bundles had attained a certain size, women spun yarn and wove on their mobile looms. Durable strips of woven fabric would then be stitched tightly together. The fabric would shrink during the dry, warm season and expand and become so to say waterproof during the cold season. Black tents (regardless of type), would be held up by loops and toggles over a solid ridge pole. The 
527 Tibetan tent was erected without an apex outlet, unlike the Sámi’s lavvu. Smoke escaped

528 through and rays of daylight or moonlight penetrated the fabric. The thick cloth was water

529 resistant thanks to the wool's lanoline and soot from the oil from burnt dung. Returning to our

530 introductory discussion on how to theorize a nomadic dwelling, those who made and dwelled

531 in yak tents had arguably far more than a protective shelter.

532

533

534

535

536

537

538

539

540

541

Three poles were connected to the ceiling board and held the tent upright. The innermost pole was sacred, adorned with a traditional silk scarf, juniper leaves, and wool from dead or live sheep whose lives were spared as acts of compassion. A ritually installed fireplace was in the center, dividing the tent into two halves. Without a properly ritually installed hearth taming unruly malevolent influences, purifying the place and installing protective deities, a tent and a camp would be uninhabitable. Intricate codes and social arrangements regulated where household members and guests sat, worked, and slept. The yak tent's covered ground formed a membrane between the human dwellers and an underworld of volatile spirits, which they sought to tame by enacting powerful appropriation rituals. Toward the end of a season, the nomads would dismantle their abodes and put them up in a new camp. They mounted their disassembled tents and household goods onto waiting yaks or horses. Only the fireplace was left behind, meticulously covered, in expectation of returning. The Tibetan notion of sacred hearth was not unlike the religious idea of the Sámi of a hearth, which was an abode for deities and hence sought preserved in anticipation of later returns to old camp sites (Anderson et. al 2013; Storm, 2015). In our analysis, the permanency of the ritually installed fireplaces in western Tibet turned them into sites for protective deities, constituting powerful pegs connecting heaven and earth and making any encampment realm spiritually inhabitable - a place humans and animals could shelter and find sustenance.

Caravans of heavily laden animals and humans could move across realms or "landscapes" using celestial coordinates, place memory, and their flocks' instinctive 
552 knowledge of migration routes. As nomadic society evolved, settlement realms became

553 relatively well-defined territorially. Nomads knew their own realm intimately and felt

554 custodianship for its wildlife, water sources, and meadows. Though we have not come across

555 visual material comparable to the debated front cover of the book written by the Swedish

556 cleric Schefferus (1673), his portrayal of a hunting band on the move could have illustrated

557 daily mobility in the Tibetan Plateau. On reaching any destination, tent pitching relied on

558 customary practices, a degree of central and local administrative regulation and extremely

559 careful attention to religious, meteorological, and hydrological conditions. As long as one

560 moved within an established territory, people pitched their tents over treasured ancient

561 fireplaces. When Chang Tang's newly arrived nomads out of necessity or simply to

562 demonstrate coercive power, expanded their realms and crossed into other's territory, they

563 would have to make their tents spiritually inhabitable by installing new hearths.

The Tibetan black tent can profitably be conceptualized as an assemblage of cosmological notions enacted in skilled practices, comprising place-making rites, the notion of a sacred pole, the plucking of hairs from yaks and the craft of producing this superbly durable woven material. Tents were taken down and carried on yak or horseback across encampment realms harboring pastures, springs, wetlands, salt mines, and huge rocks - the abodes of spirits. Ingold's theoretical insistence on the cosmological underpinnings of making and unmaking a nomadic dwelling holds true. His extended argument about a fundamental difference between a nomad's tent and a farmer's lodge seems more problematic. Our historical data suggest that a sizable number of Drongpa migrants came from farming communities and apparently managed to shift to a nomadic life, no doubt aided by cohabiting, intermarrying with members of herding units who came from nomadic communities and with whom they formed bands. Such evidence raises circumstantial doubts about any fundamental difference between these dwelling complexes. If our historical data had contained specific 
577 information about flawed designs and lack of functionality and skills as a direct cause of

578 morbidity and mortality, we could have been more specific. What does constitute more solid

579 evidence of transitional dwelling forms are the nomads' place-making rites. Headed by

580 revered monks, these rites centered on installing hearths as sacred abodes built on a

581 cosmological (mandalic) model of hierarchical purity, adopted from the cosmological design

582 of monasteries as pure sacred centers (Bleie and Tsering 2017, 13).

\section{Revisiting state authority-pastoralist society through a comparative lens}

Now, returning to the broader historical context, historical data reveal the drivers behind the formation of early nomadic society in Chang Tang also show that even the first generation of newcomers were competing with each other for the most attractive meadows and sources of drinking water. Drongpas, who were skilled in the martial arts mobilized large groups of herders, and used a combination of persuasion and outright intimidation to gain access to valuable resources. About 50 Drongpa households settled along the Sengge Khabap river north of the sacred Kailash by negotiating and applying pressure, forming three nomadic settlements. In recognition of the importance of their clan back in Eastern Tibet they named their nomadic realms Drongpa Tsosum, which literally means "the three nomadic realms of the Drongpa people" (Tsering 2006, 70). Drongpa Tsosum's territory was rich in water, grassland, wildlife, and salt. Over the years, news of their success as pastoralists reached people back in their old homeland, encouraging a new wave of Drongpa migration from Eastern to Western Tibet. A protracted accumulative migratory process had begun.

At this stage of Chang Tang's settlement history, the Drongpa Tsosum had become a local state-sanctioned dynamic herding community. Herders were defined as subjects, to be taxed for each yak they owned. The tsosum was directly administered by an official (Garbon) 
601

602

603

604

605

606

607

608

609

610

611

612

613

614

615

616

617

618

619

620

621

622

623

624

625

who was the General Administrator (Tsering 2006, 70). The emerging local governance structure (Tshul kriam 2003, 21-24) had four tiers of officials and gave the government in the capital Lhasa an opportunity to obtain benefits apart from the lucrative income from taxation. The structure also provided local chieftains with an entirely new type of political and judicial authority, including arbitration rights, rights to local taxation, and different kinds of labor services.

Returning to Northern Fenno-Scandinavia, the influential historian Lars Ivar Hansen's (se e.g. 2012, 2013) research on the interfaces between the coastal and inland Sámi and surrounding state formations from the late Middle Ages onward, provides a rare and useful empirical intake to uncover the drivers and outreach of settlements. Reliable taxation lists, constitute a prime source of evidence. They represent a fascinating historical testimony of how the Sámi population became subjected to state expansion from at least three different centers. From the west and south the kingdom of Norway-Denmark extended influence, from the south the Swedish kingdom enlarged their presence and from east Russian and Karelian tax collectors and private traders or birkarler (Bergmann and Edlund 2016). All these states shared a European peasant civilization outlook. Their elites craved after luxurious furs. The monarchial and imperial authorities vied to fill state coffers from tax on the flourishing regional trade. The fact that these colonial incursions did not in this phase lead to mass impoverishment and indebtedness, is more of a testimony to continued relative sovereignty of Sámi peoples of Northern Fenno-Scandinavia than self-imposed self-restraint in Copenhagen, Stockholm and St. Petersburg.

In light of such consequential historical evidence about the taxation system of Sámi nomads and semi-nomads in the late sixteenth and early seventeenth centuries, let me highlight certain comparable findings on taxation in the early nomadic formation we are currently researching. Chang Tang's herders were obliged to pay a herding tax. Clusters of 
626

627

628

629

630

631

632

633

634

635

636

637

638

639

640

641

642

643

644

645

646

647

648

649

650

three nomadic households shared joint responsibility for herding ewes. In addition, one of the households was obliged to herd yaks, and another to herd packing sheep, used to transport the commercially valuable salt and other goods. Finally, one household in each cluster was put in charge of herding lambs. Housekeeping constituted another area of labor. The chief's family was entitled to have thirteen male and female servants, who took care of all kinds of daily household chores. A final domain of labor service was the arduous task of moving livestock and people between summer, autumn, and winter pastures. When the chief's family moved from summer to autumn pastures, three $T$ so were obliged to provide 60 yaks and six persons. Before moving to the winter pastures, the head family could compel three Tso to provide 40 yaks and four laborers. The lucrative trans-Himalayan salt trade constituted another area that involved tributary labor arrangements. Three $T s o$ were annually responsible for providing three persons to transport the salt to its destination on behalf of the chief. Collected tax in cash was submitted to the local government in Lhasa.

Analysis of this multi-tier governance structure makes it evident that resource extraction and property accumulation in Chang Tang's early nomadic society were based on a pastoral regime that entailed a range of labor obligations. The measuring unit was a lab: one yak equaled one $l a b$; seven sheep equaled one $l a b$; and $12 l a b$ were assessed as the equivalent cash tax of one dramgar, the erstwhile currency (Tsering 2006, 360-366). In order to acquire the cash necessary to fulfill tax obligations, herders relied on income from the lucrative salt trade and trade in animal products. Again relating our tax data and preliminary findings to the innovative studies of Hansen (quoted above), we do not have taxation lists for extensive periods, providing detailed information on many identifiable individuals, herding and dwelling units. As debated, the extraordinarily comprehensive royal tax lists allowed Hansen to construct detailed social maps showing intricate mobility and settlement patterns between inland and fjords and within watersheds. Our archival data on the early tax system in Chang 
651 Tang do not provide systematic tax lists of generations of taxpayers. The data sets

652

653

654

655

656

657

658

659

660

661

662

663

664

665

666

667

668

669

670

671

672

673

674

675

nevertheless provide novel and important insights into the rise of an elaborate, multi-tiered taxation system. It was both as a result of indirect governmental intervention in a peripheral frontier society using local Drongpa chiefs as intermediaries who had allowed themselves to be co-opted into the governance system, in exchange for hereditary rights to local taxes and labor services. In other words, this taxation system led to hierarchical differentiation between Drongpa sub-clans within settlement realms. Such stratification processes are not reported by Hansen, Bjørklund and Sara in their seminal studies of the Mountain and Sea Sámi.

Efforts have been made to piece together certain salient features of the Western

Tibet's governance system in a context of mobile settlements and herds in the late seventeenth and eighteenth centuries into a jigsaw puzzle, painstakingly retrieved from various archival data and oral sources. The organization was semi-formalized and characterized by increasing social stratification based on hereditary, gendered, and clan-related status, in terms of rights to offices, pastures, tax and labor obligations. The social and political organization also incorporated tribal traits based on well-tested customary nomadic practices in the source communities back in eastern Tibet in vital areas of decision-making, including arbitration of local disputes, in which pasture rights dominated (Goldstein 1971 a, b; Kensaku 2014). The so far largely undocumented historical development in Chang Tang entailed the establishment and institutionalization of incipient governance and settlement structures as the dynamic outcomes of negotiations and compromises between an increasingly diverse nomadic population in Chang Tang and a centralized power center in Lhasa with an extremely limited immediate presence. Given the climatic and topographical variations and the importance of balancing herding, hunting, and trade, Chang Tang's nomads cultivated necessary contacts with local monastic communities, itinerant traders, sages, pilgrims, and seasonally present representatives of the high lords in distant Lhasa. Hansen's historical study of the network of 
676 reindeer herders in Finnmark, exposed a similar complexity in terms of scale (both numbers 677 and outreach).

\section{Conclusion}

679 This paper represents an early effort to advance a comparative approach to the study of historic settlements in Northern Fenno-Scandinavia and Western Tibet. The fundamental premise for this enquiry is that it makes sense to compare the Sámi of northern Scandinavia and pastoralists of the western Tibetan plateau and that it may yield important comparative insights for two so far rather insulated scholarly communities. My point of departure has been to attempt to establish elements of a foundation for a reframed approach to the settlementdwelling nexus, set within a contextual analysis of historical change. Applying insights from theoretic contributions of social and cognitive anthropologists, historians, and archeologists, the settlement-dwelling nexus is situated within an overarching understanding of certain fundamentals of pastoralist regimes in general. The dynamic interfaces between pastoralists and agricultural civilizations, which include pastoral regimes' contact with, and even some degree of incorporation into state formations (including trade networks, taxation, land and settlement policies), and the diverse, sophisticated skill base of pastoralists, their social fabric, transhumance cycles, and conservation practices - all constitute such overarching fundamentals. of settlement. On the contrary; the unique nature of mobile settlement realms, in several respects constitute the dwelling as a system of religious ideas and functional, intricately ordered interior place. In terms of spatial outreach settlements could fluctuate, and at times

698 attain an enormous scale (based on negotiated or appropriated user rights to pastures and water) and constituted diverse local ecologies, with which humans and livestock had to 
700

701

702

703

704

705

706

707

708

709

710

711

712

713

714

715

716

717

718

719

720

721

722

723

724

engage, and from which they reaped natures' bounty. Apart from sheltering people and livestock under extreme conditions, nomads crafted their dwellings as microcosms of an outdoor life-world in which humans and semi-domesticated reindeer and yaks co-existed in mutual affection, trust, inter-dependency and a certain amount of brutality and objectification. This was arguably the case as pastoralism's inner logic restructured herders-herd relations. Ingold's intriguing theoretical proposition about a categorical difference between a nomad's and a farmer's dwelling has proved useful to think with. Especially so, when grappling with an analysis of ethnographic and archival evidence of transitions from sedentary/semi-sedentary to full-fledged mobile societies and of transitions from a pastoral adaptation to sedentary and semi-sedentary life in close proximity of sedentary settlements, be they farming villages, fishing communities, market places, government outposts or monasteries.

This preliminary scrutiny of historical dwelling designs and practices of Sámi and Tibetan pastoralists indicates that nomads in both regions internalized and activated different spatial models and inventively mediated between different spatial models according to seasonal shifts or irreversible shifts of leaving the nomadic adaptation altogether. The examined works on the Northern Sámi during the heyday of pastoralism show how they shifted between highly mobile and semi-permanent dwellings and settlements. Moreover, a trickle of nomads abandoned over generations a specialized pastoralist adaptation and resettled in permanent Sea Sámi settlements, carving out a living by combining fishing, agriculture, husbandry, and hunting. The fact that the same term goahti was applied for the permanent (bealljigoahti) lodging (Bjørklund 2013b, 79) might lend support to the continuity argument. This being so, evidence of a more fine-grained ethnographic and architectural nature would nevertheless be important for a fuller understanding of the interfaces between cosmological notions, functional design, and everyday dwelling practices. Here one can hope 
to unravel empirically processes of accommodation, innovation, and possible unmediated gaps. If significant unmediated gaps are found, they could obviously be interpreted in light of Ingold's theoretical argument of a fundamental difference between the nomadic tent and the farmers lodge.

Ongoing research on spatial models of Tibetan nomads of the seventeenth and eighteenth centuries, reveal they were conversant with monastery complexes, which were architecturally designed monumental buildings centered on a cosmological (mandalic) model of hierarchical purity. Somewhat unexpectedly, we have found the same spatial model underpins the obligatory place-making rites enacted for installing a hearth before raising any tent. Our finding that a not insignificant number of early nomads originally came from farming communities in Eastern Tibet, a region of powerful manorial estates and Buddhist monasteries of different sects, may represent another piece in the historical puzzle. It helps explaining this particular aspect of spatial continuity, notwithstanding other, no doubt significant differences between a disassembled/assembled tent and a permanent farmer's lodge.

The expanding research frontier on the origin question of Sámi pastoralism may profitably be related to the ongoing study of the origin of yak nomadism and early settlements in southwestern Chang Tang. We have discussed three major strands of thought on the origin of Sámi pastoralism. One emphasizes external drivers and a second strand accords primacy to internal factors. A third position, advocated by Bjørklund amongst others, calls for a more balanced two-sided approach, weighing several internal and external drivers.

Our story of the rise of yak nomadism in Chang Tang differs from the origin story of reindeer nomadism in one particular sense: we are unraveling the expansion of a specialized herding and dwelling mode though a dramatic east-west migratory process, not the origin of a 
specialized herding mode per se. This qualification aside, our explanatory framework accords importance to a mix of external and internal factors and illuminates how closely macro-mesomicro conditions connected and motivated regional transmigration over successive generations. This protracted migratory history led to the rise of a pastoral society in this corner of the Tibetan plateau. Our findings here are in line with Bjørklund's critique on the so-called shift argument. Turmoil in the late seventeenth century caused by contending regional powers, spread and engulfed the farming and nomadic territories in Kham and Amdo, which became the source communities of an east-west mass migration. They brought their precious black yak tents with them. Important internal factors behind the risk-prone migration across treacherous high mountains spanned from devastating local clan feuds, prosecution, desire to escape hardship on manorial estates, to religiously colored tales of blissful faraway lands of unlimited pastures near the sacred Mount Kailash. As importantly, the early flocks of long-distance migrants-cum-pilgrims numbered not only impoverished farmers, professional soldiers, and convicts, nomads too migrated, bringing with them a critically important skill base of herding and living in the ingeniously adapted yak tent, whose sacral and mundane interior organization epitomized a life-world of intimacy and mutual interdependence of herders and herd. Our findings are comparable with Bjørklund's argument that changes in settlement patterns were a direct effect of a transition, rather than a shift from hunting to pastoralism. With the rise of pastoralism, the sturdy bealljigoahti became a principal mobile dwelling (a turfmade permanent variety of it was used in coastal areas), while the lighter conical lavvu was also in use during seasonal migrations. Both designs were ingenious adaptations and functioned to accommodate dwelling requirements during migrations and stationary seasons under the new extensive herding regime.

Our investigations have successfully mapped important facets of the rise of flexible bands. Bands were composed of tent dwelling nuclear and extended Drongpa households, 
774

775

776

777

778

779

780

781

782

783

784

785

786

787

\section{Endnotes}

\footnotetext{
${ }^{1}$ The notion "first and third pole" originated in contemporary scientific discourse on global environmental change. The term presupposes that effects and processes of climate change on the South and the North Poles and in the "third pole" - the extended Himalaya and Tibetan Plateau - shows notable similarities. The Tibetan Plateau is the largest high-altitude landmass on the globe. The third pole is the globe's water towers with the third largest fresh water reserve after Arctic and Antarctic.

${ }^{2}$ I like in particular to acknowledge the invaluable comments of my project lead partner and colleague Dawa Tsering, Senior Scholar at Tibet Academy of Social Science (TASS) in Lhasa (TAR). The Network for University Co-operation Tibet-Norway has solicited essential external financial support. Other institutional support was provided by UiT- The Arctic University of Norway.
} 


\footnotetext{
${ }^{3}$ The notion landscape has an arch-European origin in Dutch landscape painting, landskip in Dutch and landskap in Norwegian.
}

\section{Disclosure Statement}

No potential conflict of interest has been reported by the author.

\section{References}

Anderson, David G., Robert P. Wishart, and Virginie Vate, eds. 2013. About the Hearth. Perspectives on the home, hearth and household in the Circumpolar North. New YorkBoston: Berghahn Books.

Barth, Fredrik. 1959. Political Leadership Among the Swat Pathan. London: Athlone Press.

Barth, Fredrik. 1961. Nomads of South Persia. Oslo: Oslo University Press.

Barth, Fredrik. 1966. Models of Social Organization. Occasional Paper No. 23. London: Royal Anthropological Institute.

Barth, Fredrik. 1969. Ethnic Groups and Boundaries. Boston: Little Brown.

Bergman Ingela, and Lars-Erik Edlund. 2016. "Birlkarler and the Sami-inter-cultural contacts beyond state control: reconsidering the standing of the external tradesmen in medieval Sámi societies." Acta Borealia, 33 (1): 52-80.

Brantingham P.O, J. W. Olsen, and G.B. Schaller. 2001. "Lithic assemblages from Chang Tang Region". Antiquity: 319-327.

Berkes, Fikret. 2008. Sacred Ecology. 2nd. ed. New York-London: Routledge.

Berkes, Fikret and M. Berkes 2009. "Ecological Complexity, Fuzzy Logic and Holism in Indigenous Knowledge". Futures 41 (1): 6-12.

Bjørklund, Ivar. 2013a. "Domestication, Reindeer Husbandry and the Development of Sami Pastoralism”. Acta Borealia: 30 (2): 174-189.

Bjørklund, Ivar. 2013b. “The Mobile Sámi Dwelling: From Pastoral Necessity to Ethnopolitical Master Paradigm". In About the Hearth: Perspectives on the Home, Hearth and Household in the Circumpolar North, edited by David G. Anderson, Robert P. Wishart and Virginia Vaté, 69-79. New York: Berghahn.

Bleie, Tone and Dawa Tsering. 2017. "Historic Migration in China: Chang Tang from wilderness to inhabited frontier society". Online prepublication Dec. 2017, Journal of Migration History (JMH), 4(1): 1-32. Doi: 10.1163/23519924-00401001. .

Blondeau, A-M., E. Steinkellner, eds. 1996. Reflections on the Mountain: Essays on the History and Social Meaning of the Mountain Cult in Tibet and Himalaya. Wien: Verlag der Østerreichischen Akademie der Wissenschaften. 
Broch-Due, Vigdis. 1991. "Cattle are Companions, Goats are Gifts: Animals and People in Turkana Thought". In From Water to World-Making: Arid Lands and African Accounts, edited by G. Pallson, 39-58. Uppsala: Scandinavian Institute of African Studies.

Broch-Due, V. 1993. "Making Meaning Out of Matter: Perceptions of Sex, Gender and Bodies among the Turkana". In Carved Flesh, Cast Selves: Gendered Symbols and Social Practices, edited by T. Bleie, V. Broch Due and I. Rudie, 53-82. Ann Harbor: Berg Publishers.

Ches, Ngags. 2010. Gangs dkar ti si dang ma pham guy mtsho’ gnas yig. Lhasa.

Dorji, Tsechoe; Joseph L. Fox; Camille Richard and Kelsang Dondrup. 2010. “An Assessment of Nonequilibrium Dynamics in Rangeland of the Aru Basin, Northwest China". Rangeland Ecology and Management. 63(4): 426-434.

Dowman, Keith. 1997. The Sacred Life of Tibet. Glasgow: Thorsons.

Dwyer, M. J and K.V. Istomin. 2008. "Theories of Nomadic Movement: A New Theoretical Approach for Understanding the Movement Decisions of Nenets and Komi Reindeer Herders”. Human Ecology Vol 36:521-533. Doi:10.1007/s10745-008-9169-2

Falkenberg, Johs. 1941. Bidrag til finnernes bygdehistorie og etnologi. Bosetningen ved indre Laksefjord i Finnmark. Annet hefte. In Nordnorske samlinger: Oslo.

Fox, L. Joseph, Per Mathiesen, Drolma Yangzom, Marius W. Næss and Xu Binrong. 2004. "Modern wildlife conservation initiatives and the pastoralist/hunter nomads of northwestern Tibet". Rangifer: Special Issue (15): 17-27.

Fox, L. Joseph, and Dawa Tsering. 2005. "Biodiversity conservation and natural resource exploitation on Tibet's northwestern highlands". In Wildlife and plants in tradition and modern Tibet: conceptions, exploitation and conservation, edited by A. Boeis and F. Cardi. (33) 1: 49-57. Memorie della Società italiana di scienze naturali e del Museo civico di storia naturale di Milano: Milan.

Gaerrang, Kabzung. 2015. "Housing Projects in the Nomadic Areas of China's Eastern Tibetan Plateau: Representation, Market Logic and Governmentality." Nomadic Peoples 19 (2): 261-280. Doi:10.3197/np.2015.190207

Goldstein, Melvyn. 1971a. "Taxation and the Structure of a Tibetan Village". Central Asiatic Journal 15 (1):1-27.

Goldstein, Melvyn. 1971b. "The Balance between centralization and decentralization in the Traditional Tibetan Political System”. Central Asiatic Journal 15 (3): 170-182.

Grosvenor, G.M 1986. "Generations of cooperation: the New York Zoological Society". National Geographic 169 (6): 3-5.

Hansen, Lars Ivar and Bjørnar Olsen. 2004. Samenes historie fram til 1750. Oslo: J.W. Cappelens Forlag. 
Hansen, Lars Ivar. 2012. "Networks, Diversity and Mobility among the Northern Sami in the 16th. Century”, 217-239. In Memoires de la Société Finno-Ougerienne, 265: Helsinki.

Hansen, Lars Ivar. 2013. "Skattelister som kilde til mobilitet blandt samene på 1500-tallet". In Nord-Norge i Europa: Arkeologi, historie og kulturvern, edited by H.P. Blankholm, H. D. Bratrein, J. E. Arentzen and K. Lind. 77-94. Troms $\varnothing$ Museums Skifter Vol. 34. Troms $\varnothing$ Museum: Universitetsforlaget.

Hirsch, Eric and Michael O'Hanlon, eds. 1995. The Anthropology of Landscape:

Perspectives on place and space. Oxford: Clarendon Press.

Huber, Toni and Tsepak Rigzin. 1995. "A Tibetan Guide for Pilgrimage to Ti-S (Mount Kailash) and mTsho Ma-phan (Lake Manasarovar)". Tibet Journal. Special Edition: Powerful Places and Spaces in Tibetan Religious Culture 20 (1): 9-46.

Huber, Toni and Stuart Blackburn, eds. 2012. Tribal Cultures in the Eastern Himalayas: origins and migrations in the Extended Eastern Himalayas. Leiden: Brill.

Ingold, Tim. 1985. "Khazanov on Nomads”. Current Anthropology 26 (3): 384-387.

Ingold, Tim. 2000. The perception of the Environment: Essays in Livelihood, Dwelling and Skill. London: Routledge.

Ingold, Tim. 2011. Being Alive: Essays on Movement, Knowledge and Description. London: Routledge.

Ingold, Tim. 2013. "The Conical Lodge at the Centre of the Earth-Sky World". In About the Hearth: Perspectives on the Home, Hearth and Household in the Circumpolar North, edited by David G. Anderson, Robert P. Wishart and Virginia Vaté, 11-29. New York: Berghahn.

Khazanov, A. M 1984. Nomads and the Outside World. Cambridge: Cambridge University Press.

Kensaku, Okawa. 2014. "Land-centered Perspective: A New Way of Looking at Tibetan Traditional Society". Journal of Research Institute: Historical Development of Tibetan Languages Vol. 51: 391-405.

Low, Setha M., and Denise Lawrence-Zứniga eds. 2003. The Anthropology of Space and Place: Locating Culture. Oxford: Blackwell Publishing.

Magga, Ole Henrik, Nils Oskal and Nils M. Sara. 2001. Dyrevelferd i samisk kultur. Rapport 19 (11). Oslo: Landbruksdepartementet.

Moore, Henrietta L. 1986. Space, text and gender: an anthropological study of the Marakwet of Kenya. Cambridge /New York: Cambridge University Press.

Niemi, Einar. 1983. “Byggeskikk og arkitektur i Finnmark”. In FNTBs Årbok. 
Nilsen, Ragnar and Jens Halvdan Mosli. 1994. Inn fra Vidda: Hushold og фkonomisk tilpassning i Guovdageaidnu 1960-1993. Rapport SF No. 17. Tromsø: NORUT Samfunnsforsking.

Næss Marius Warg. 2013. "Climate change, risk management and the end of nomadic pastoralism". International Journal of Sustainable Development and World Ecology 20 (2): 123-133.

Oskal, Nils. 1995. Det rette, det gode og reinlykken. Universitetet i Troms $\emptyset$.

Petterson, Arvid. 2013. Hus i Finnmark. Second Edition.Vadsø: Fortidsminneforeningen.

Ptackova, Jarmila. 2015."Hor - A Sedentarisation Success for Tibetan Pastoralists in Qinghai?" Nomadic Peoples 19 (2): 221-240. Doi:10.3197/np.2015.190205

Sara, Nils Mikkel. 2015. Being siida- on the relationship between siida tradition and continuation of the siida system. $\mathrm{PhD}$ dissertation. Troms $\emptyset$ : University of Troms $\emptyset$ - the Arctic University of Norway.

Schefferus, J. 1956 [1673]. Lappland. Nordiska Museet. Acta Lapponica 8. Uppsala: Almquist \& Wiksell.

Seguin-Orlando, A., Thordfinn S. Korneliussen, Martin Sikora, Anna-Sapfo Malaspinas, Andrea Manica, Ida Moltke et al. 2014. "Genomic structure in Europeans dating back at least 36,200 years”. Science Express, 6th. November: 1-6.

Shore, B. 1996. Culture in Mind. Cognition, Culture and the Problem of Meaning. Oxford: Oxford University Press.

Storm, Dikka. 2015. "The Complex Religious Situation in the Mission District of Senja and Vesterålen in the Early Eighteenth Century". Paper presented at the Bodding Symposium, Oslo, November 3-5.

Tsering Dawa and Tone Bleie. 2016. The Chang Tang Plateau: new evidence of historic migration. China Tibetology 28 (2): 57-85.

Tsering Dawa and Tone Bleie. 2017. “阿里地区历史移民研究”, (Historical Migration Study of Nagri Region). Tibetan Studies 36 [161] (1): 85-93.

Tsering, Gyalpo. 2006. Mngav-ris-ches-vbyung-gangs-ljongs-mdez-rgyan-zhes-by-babzhugs-so. Lhasa: Tibet Autonomous Region.

Vorren Ørnulf. 1978. "Bosetting og ressursutnytting under veidekulturen og dens differensiering. Finnmarksviddas natur-kultur”. 144-181. In NOU 18A. Oslo: Statens Forvaltningstjeneste.

Wheelersburg, Robert and Natalia Gutsol. 2010. "Traditional Saami reindeer herding village resource territories on the western Kola Peninsula, Russia”. Polar Record 46 (238): 222-232. Doi:101017/S0032247409990106 
Yangzong C. 2006. The Household responsibility contract system and the question of grassland protection - a case study from the Chang Tang, north-west TAR, MSc diss., University of Troms $\varnothing$. 